\title{
Accounting as Applied Ethics: Teaching a Discipline
}

\section{Wilfred Dolfsma}

\begin{tabular}{|l|l|}
\hline \multicolumn{2}{|l|}{ ERIM REPORT SERIES RESEARCH IN MANAGEMENT } \\
\hline ERIM Report Series reference number & ERS-2005-065-ORG \\
\hline Publication & November 2005 \\
\hline Number of pages & 10 \\
\hline Persistent paper URL & \\
\hline Email address corresponding author & wdolfsma@rsm.nl \\
\hline Address & Erasmus Research Institute of Management (ERIM) \\
& RSM Erasmus University / Erasmus School of Economics \\
& Erasmus Universiteit Rotterdam \\
& P.O.Box 1738 \\
& 3000 DR Rotterdam, The Netherlands \\
& Phone: + 31 10 408 1182 \\
& Fax: + 11 10 408 9640 \\
& Email: info@erim.eur.nl \\
& Internet: www.erim.eur.nl \\
\hline
\end{tabular}

Bibliographic data and classifications of all the ERIM reports are also available on the ERIM website: www.erim.eur.nl 


\section{ERASMUS RESEARCH INSTITUTE OF MANAGEMENT}

\section{REPORT SERIES}

\section{RESEARCH IN MANAGEMENT}

\begin{tabular}{|c|c|}
\hline \multicolumn{2}{|c|}{ ABSTRACT AND KEYWORDS } \\
\hline Abstract & $\begin{array}{l}\text { In this article it is argued that there are notable parallels between all of the different strands } \\
\text { within ethics on the one hand, and accountancy on the other that, in teaching, can be drawn } \\
\text { upon to enhance students' understanding of the latter. Accountancy, part of economics, draws } \\
\text { on utilitarian ethics, but not solely so. Accounting, in addition, draws on deontological and } \\
\text { communitarian strands in ethics. The article suggests that the teaching of accounting - } \\
\text { especially to non-economists - would benefit substantially from highlighting and developing } \\
\text { these parallels. }\end{array}$ \\
\hline Free Keywords & Accounting, Ethics, Teaching Accounting, Utilitarianism, Deontology, Communitarian Ethics \\
\hline Availability & $\begin{array}{l}\text { The ERIM Report Series is distributed through the following platforms: } \\
\text { Academic Repository at Erasmus University (DEAR), DEAR ERIM Series Portal } \\
\text { Social Science Research Network (SSRN), SSRN ERIM Series Webpage } \\
\text { Research Papers in Economics (REPEC), REPEC ERIM Series Webpage }\end{array}$ \\
\hline Classifications & $\begin{array}{l}\text { The electronic versions of the papers in the ERIM report Series contain bibliographic metadata } \\
\text { by the following classification systems: } \\
\text { Library of Congress Classification, (LCC) LCC Webpage } \\
\text { Journal of Economic Literature, (JEL), JEL Webpage } \\
\text { ACM Computing Classification System CCS Webpage } \\
\text { Inspec Classification scheme (ICS), ICS Webpage }\end{array}$ \\
\hline
\end{tabular}




\title{
Accounting as Applied Ethics: Teaching a Discipline
}

\author{
Wilfred Dolfsma \\ Erasmus University Rotterdam \& Maastricht University; \\ 2005/6 fellow Netherlands Institute for Advanced Studies \\ Visiting research fellow University of Aberdeen Business School \\ Correspondence: RSM Erasmus University \\ PO Box 1738, NL-3000 DR Rotterdam \\ The Netherlands \\ Ph. +31-01-4081948 \\ Fax $+3-10-4089014$ \\ Email wdolfsma@rsm.nl
}

Keywords: accounting, ethics, teaching accounting, utilitarianism, deontology, communitarian ethics.

Abstract: In this article it is argued that there are notable parallels between all of the different strands within ethics on the one hand, and accountancy on the other that, in teaching, can be drawn upon to enhance students' understanding of the latter. Accountancy, part of economics, draws on utilitarian ethics, but not solely so. Accounting, in addition, draws on deontological and communitarian strands in ethics. The article suggests that the teaching of accounting especially to non-economists - would benefit substantially from highlighting and developing these parallels. 


\section{Accounting as Applied Ethics: Teaching a Discipline ${ }^{1}$}

Often regarded with a degree of cynicism, accounting is sometimes perceived merely as a particular way of controlling processes in businesses, even of allowing for and facilitating exploitative relationships (Lovell 1995). In addition, accounting is claimed to have led to the emergence of 'economic man' (Bhimani 1994). The practice of accounting has itself done little to create a more favorable view of the discipline either - picturing it as a discipline not only where ethical considerations play no role, but may even be alien. People generally, however, seem to interpret their world in ethical terms, be it informed or uninformed by ethical theory. Note that this is not an argument in favor of moral intuitionism, such as proposed by G.E. Moore (1903). Rather, it points to how people's everyday, implicit views of ethics affect their behavior, including in the classroom. ${ }^{2}$ Aristotle in his Nicomachean Ethics notes the etymological relation between ethics (or $\dot{\eta} \theta 0 \varsigma$, "virtue of character" as he refers to it) and habit ( $\dot{\varepsilon} \theta$ $)$. As Peacock (2004) observes about Aristotle’s position: "Thus if we get into the habit of acting virtuously (by performing virtuous acts), we will acquire a virtuous character.” French renaissance philosopher, Michel de Montaigne (1991), concurs for one. The ethical understandings that people have tend to be rather implicit and are subject to development. ${ }^{3}$ When teaching accounting, therefore, particularly to students majoring in other disciplines, one is faced with the challenge of trying to present a perspective of the world that at first sight would seem alien to many people. It would seem that this is especially the case for students in the (liberal) arts and for those in engineering.

Having been trained in accounting or economics, in many cases, professors who teach accounting tend to view the world differently. The willingness of economics students to cooperate is significantly lower than that of other students, for instance (Frank, Gilovich \& Regan 1993). Whether this is due to self-selection or a consequence of the curriculum taught is unclear. What is clear is that the process of attaining a Ph.D. in economics is perceived as a difficult one in which especially one's frame of mind and perspective on the world is changed (Klamer \& Colander 1990).

While in economics people are seen to be motivated by their (material) self-interests, non-economists are inclined to conceive of people's behavior as driven also by social and ethical demands. As Rosenau (2004) argues, this does not mean that self-interest does not play a role, or will never play a dominant role. What it does mean is that a minority of people will always initially be inclined to pursue self-interest only (free-riding). When teaching accounting, I submit, presenting constitutive ideas and concepts of the discipline as ethical in nature will assist in teaching because the concepts may relate more directly to the audience's frame of reference. ${ }^{4}$ Accounting is a discipline that is thoroughly ethical in nature (cf. Francis 1990), as is proposed below, and making this clear in class might further students' understanding of accounting. There is no systematically collected evidence on which to base what is proposed in this paper, unfortunately. However, experience has indicated that there is merit to the suggestion of presenting accounting as applied ethics especially to students

\footnotetext{
${ }^{1}$ The author would like to thank Christopher Houghton Budd and two anonymous referees for their helpful and stimulating comments and suggestions; the usual disclaimer holds, needless to say.

${ }^{2}$ Cf. Klamer \& Colander (1990).

${ }^{3}$ There is a discussion of the possibility, the nature as well as the course of moral development (see for instance: Carr 1991, Crittenden 1990, and Kohlberg 1981, Rest 1986).

${ }^{4}$ Cf. Geary \& Sims (1994) on the choice of pedagogy to teach accounting.
} 
who major in other disciplines. In addition, it might also legitimate accounting's place in society to emphasize how accounting can be perceived as applied ethics. Section 1 briefly discusses the relation between economics and ethics, without intending a review of the literature (see Hausman \& McPherson 1993). ${ }^{5}$ Ethics will only be discussed in rather broad strokes, enough to indicate the parallels with accounting, but not nearly enough to exhaust this topic. If the latter is one's purpose, one would have to consult other sources (e.g., Beauchamp 1982). In a way, Section 1 of the paper can be seen as background for teaching accounting as if it were applied ethics. The latter is developed in Section 2. This article draws on the existing literature on the professional ethics of business students and accounting professionals. ${ }^{6}$

\section{The Ethical Bases of Economics and Accounting}

The founder of economics, Adam Smith, during his life professor of Moral Philosophy at the University of Glasgow, considered an inquiry into the causes and nature of the wealth of nations impossible without relating such an inquiry to morality and moral sentiments. Indeed, long before he published his Wealth of Nations (1976 [1776]), he published The Theory of Moral Sentiments (1976 [1759]). To illustrate, while there is only one mentioning of the renowned 'invisible hand' in the former, there are two in the latter.

One important distinction within ethics is between deontological and consequentialist perspectives. The first one stresses the rights that people have, and the necessity for people to respect other people's rights. Doing good means respecting these rights and living by ethical rules whatever the consequences. The latter perceives of the good as that which maximizes the consequences for society. An example of a consequentialist ethics is utilitarianism, which holds that the well being for society as a whole needs to be maximized, even if that involves violating the rights of some. Indeed, the concept of right sits uncomfortably within a consequentialist ethics - a point developed later in this paper.

Those versed in the history of economics have no difficulty recognizing one of the founding figures of the consequentialist perspectives as Bentham's (1970 [1823]). He was explicit in stating that the good for individuals as well as for society is to pursue the options that result in the highest levels of well-being. Bentham uses the concept happiness (“utility”) in this regard, and believed that utility would, progress in science permitting, be ultimately measurable in terms of 'utils'. ${ }^{7}$ In economics, the concept of utility is now an individualist and subjective one. As the cardinal view of utility, where it is held that utility can be measured in an objective way and thus the utility derived from a good can be compared to that derived from another good, also across individuals, is discarded and replaced by an ordinalist one where just rank-orders for a single person are believed to exist, the possibility of aggregating utility over groups of individuals is rendered impossible. ${ }^{8}$

Jevons' theoretical work (1970 [1871]) does not so much stress the need for education and upbringing as his applied work (1981) does. The combined assumptions that Jevons introduced into economics, and which form its utilitarian basis - the measure of the good 'utility', and the criterion of maximization - were not

\footnotetext{
${ }^{5}$ Arthur \& Shaw (1991) compile an excellent selection of (excerpts from) original texts.

${ }^{6}$ See Davis \& Welton (1991), Denham (1991), Francis (1990), Gray, Bebbington \& McPhail (1994), Lovell (1995), Ponemon (1992), Puxta, Sikka \& Willmott (1994).

${ }^{7}$ To see how the concept of utility was perceived of and modeled in economics since the early $20^{\text {th }}$ century, see Lancaster (1998).

${ }^{8}$ See Lancaster (1998) and Stigler (1968); for a discussion, see Dolfsma (2004).
} 
considered by him to be present in all individuals (see Bowman 1997). In particular, women and the poor were lacking (White 1994). Therefore, individuals' utility could not be the sacrosanct measure of the good as would be assumed in theory. In addition to emphasizing the value of education and family life, Jevons believed that the consumption of alcoholic beverages should not be allowed under any circumstances, no matter how much utility it would produce (Dolfsma \& Mosselmans 1999). Even if they were rationally to maximize their utility, individuals should be stopped from behaving against what would almost amount to a deontological principle.

In economics, therefore, doubts about the extent to which utility could be assumed a correct measure for well-being enters as well. As we will see later, however, unlike accounting, general economics does not allow for deontological considerations to play a role. Deontological ethics holds that real behavioral change requires rules, which need to be observed irrespective of the consequences of observing them. This perspective is generally ascribed to the $18^{\text {th }}$ century German philosopher, Immanuel Kant. His 'categorical imperative' tells people to consider how they themselves would like to be treated, and thus to develop rules that any rational human would want to see supported universally. Support for such a rule is independent of the consequences that might ensue given particular circumstances.

In exploring the parallels between economics and ethics, it is of interest to note that rules have acquired an increasingly important position in economics. The New Institutional Economics (NIE) develops the idea of ‘institutions’ that guide individuals’ behavior (e.g., North 1990). Institutions, however, are seen only to constrain people's behavior. People rationally abide by them because thereby they will attain a higher level of well-being. ${ }^{9}$ In terms of the ethical discourse, NIE departs from act-utilitarianism, whereby each separate act needs to maximize the utility of the actor, but opts instead for rule-utilitarianism, ${ }^{10}$ whereby not every act needs to maximize utility, yet by adopting certain rules utility generally is maximized. Institutions do change in response to a changing environment, but do not do so in a smooth manner. Denzau \& North (1994) conceive of this process as one of 'punctuated equilibria'.

However, deontological principles do not sit easily within economics. If economic research addresses principles or (moral) rights and makes a case for them, it tends to do so by drawing attention to their beneficial effects for society. Human rights, for instance, are sometimes defended with the use of economic arguments on the grounds that living up to these deontological principles means enhanced well-being for everybody involved (e.g., Conley \& Livermore 1996). The Pareto criterion from welfare economics is thus upheld.

Social contract theory can be considered a variant of rule utilitarianism. Typically, an original, Hobbesian position is posited, where people need to make a decision on how they want to structure society. The English political philosopher, Thomas Hobbes, was the first to undertake such an exercise. In his mind, without an almighty State, people in society would be like wolves towards one another. Knowing this, people appoint one of them (the Leviathan) to have dictatorial powers. In more recent times, Rawls (1971) has worked along such lines. He argues that, in a hypothetical original position where they do not know what the future holds for them, being under a 'veil of ignorance', people will just apply the maxi-min decision rule and based on considerations of self-interest decide to distribute primary goods equally. They choose two principles to structure society by. First, everybody is allowed the maximum amount of liberty compatible with an equal amount of liberty of others. Inequalities in the distribution of primary goods are allowed only if they benefit everyone and

\footnotetext{
${ }^{9}$ See Hodgson (1993) for an overview of 'old' and 'new' institutional economics, and their differences.
} 
particularly the least off. These principles are thus not sacrosanct. Utilitarian considerations may overrule especially the second. Rawls's view has had tremendous impact in ethics, but is taken up in economics as well see in particular the work of Donaldson \& Dunfee (1995).

In recent times, a third perspective has gained prominence, that of the communitarian perspective. Harking back to the early Greek philosopher, Aristotle (1980), the communitarian perspective argues that ethical considerations emerge from within a particular community and considers universal ethical imperatives as suspicious. Notable contributions in this area include Walzer (1983) and Van Staveren (2001). Whereas the positivist influence in economics is alien to a communitarian view (Mirowski 1989) because of its advocacy of relativist considerations, institutional economics (Hodgson 2001) is more empathetic on account of its explicit acknowledgment of historical, social or geographical specificity.

\section{Ethics and Accounting}

In teaching accountancy, especially to students with little background in economics or business, arguing that it can be perceived of as applied ethics may be useful. A case can be made that accountancy indeed has ethical bases, much like economics generally, something that can be made use of in the classroom.

Originally published in 1494 (but from 1509 in substantial numbers), the Italian, Luca Pacioli, was the first to bring out a book where the principles of double entry bookkeeping were explained. For many years after, double entry bookkeeping, which allowed for internal controls for consistency, was known as Italian bookkeeping. Would-be bookkeepers would travel to Italy to study these principles, as did painters to learn from the Italian painters of the Renaissance.

Beyond the neo-classical view, where utilitarian considerations are the sole ethical considerations, the balance has always been more towards deontological principles and even a communitarian perspective in accounting. Indeed, one reason for starting to keep accounts was a moral one: to be able to know and keep track of which individuals and organizations were due how much (de Wal 1927). An act utilitarian approach to keeping accounts would not necessarily acknowledge that obligations between any two parties should be upheld even in circumstances where violating them would result in higher happiness for society. A rule utilitarian position would probably acknowledge such obligations.

The principles of bookkeeping are more relevant in economies where transactions in money are frequent and occur in large numbers, of course. Even more, public reports about firms’ financial situations increase in their relevance when these firms are dependent on outside finance to continue their operation. This requires keeping track of who is due how much, and who owns what share in the firm. Keeping the books of such obligations could be construed as either minding the rights that different parties have towards others and thus resting on deontological considerations in ethics, or it could be construed as based on rule-utilitarianism. In this latter case, an 'as if' argument would be made saying that the rules of book keeping have nothing to do with rights and obligations, but have validity because they maximize society’s happiness (utility). This 'as if' argument would draw on Milton Friedman’s position about economic methodology (1953).

\footnotetext{
${ }^{10}$ Compare Smart (1973) on act-utilitarianism and Brandt (1967) on rule-utilitarianism. Baumol \& Quandt (1964) have presented a largely neglected argument for a rule-utilitarian position from a neo-classical point of view.
} 
The Dutch colonial East India Company (VOC) - granted a monopoly by the State to trade with the East - was the first to regularly publish such reports. The struggle within this company between management and financiers is well-known. The latter argued that the capital invested gave them a right to determine the course of the company (de Boer 1957). The Dutch East India Company was the first firm where ownership and management were separated, leading to a struggle over control wherein moral arguments played an important role.

In the $20^{\text {th }}$ century, accounting came to be seen as distinct from bookkeeping. Bookkeeping was the practice or craft of keeping track of the financial aspects of businesses whereas accounting was considered to be more scientific. Accounting involves discussing the principles that underlie the way in which accounts for institutes can be kept. Distinctions between managerial and financial accounting developed.

As mentioned earlier, in bookkeeping, the deontological aspects are clear. Indeed, there is a strong case to be made for understanding developments in the practice of accounting in terms of institutional economics, where the notion of boundaries between entities that might have moral overtones may not be violated is not an alien thought (Burns \& Scapens 2000, Dolfsma \& Dannreuther 2003). Not only is it important to keep track of who is due what, but the available budget is also divided into items that determine what the money may be used for. Spending such money in ways that are not in accordance with the purpose(s) for which the item was created is deemed a transgression that will be objected to in ways that suggest that items in a budget have moral characteristics. $^{11}$

The communitarian nature of the practice of keeping accounts is evident from the way in which the standards that they need to abide by emerged. ${ }^{12}$ A standard such as the Generally Accepted Accounting Principles in the United States (US-GAAP) has over a long period of time developed into an explicit set of rules. Prior to the 1929 downturn on the New York Stock Exchange and the subsequent depression of the economy as a whole, such rules were not made explicit and certainly not enforced. The significance of this for the present discussion is that rules for proper conduct in reporting a firm's financial position emerged from within the community itself. Thus, in an exchange between firms and the government, generally accepted accounting principles emerged on how to deal with the items in the balance sheet and income statement. Financial statements became more alike, and outsiders were in a better position to interpret them. It was hoped that sudden movements at the stock exchange - due to data provided by the companies that is difficult to understand and interpret - would then be less likely to occur, and would be less likely to have the damning effects that the 1929 events at the stock exchange had.

The US-GAAP system is now increasingly used outside of the US as the economy becomes a more global one. Other international accounting standards are considered as well, however. As firms are dependent on stake- and share-holders from outside their home country, the need for more uniform accounting standards arises. The systems that now vie for prominence have different philosophical backgrounds, reflected in the ethical connotations that they have. To varying degrees, however, both show an influence from (a part of) the community itself in the exact formulation proposed and in the way in which the rules are enforced.

\footnotetext{
${ }^{11}$ Developing the relation between accountancy standards and economic conditions more generally is beyond the scope of this short paper, given also its purpose. One pertinent contemporary issue is the extent to which economic globalization affects accountancy standards. The effects are likely to be mutual and intricate.

${ }^{12}$ In accounting literature, the terms 'anthroplogical' or 'inductive' are used.
} 
The International Accounting Standards Board (IASB; www.iasb.org.uk) and the Financial Accounting Standards Board (FASB; www.fasb.org) seem to be able to act independently, suggesting accounting rules similar to deontological ethical principles. In actual fact, however, they consult their community. On topics such as how to deal with inventories, R\&D costs, (deferred) taxes, but also the way in which financial information needs to be presented, reports are commissioned which are discussed. Each of these areas could be analyzed at greater length, discussing both how parallels with ethical considerations are evident in both the way in which accounting standards emerge as well as in their content, but this would go beyond the scope of the present paper which is exploratory and suggestive in nature. The seemingly positivist approach to accounting standards setting $^{13}$ turns out to be a communitarian type of discussion. Differences of degree remain, however, between the Continental European approach which relies more on issuing general principles, and an AngloSaxon approach which relies more on issuing larger numbers of rules for more specific situations. ${ }^{14}$ The former is more deontological, while the latter is more communitarian. In both, however, utilitarian considerations play a role. Perceiving of the process by which international accounting standards develop and are adopted across countries in terms of the different strands of ethical thought is likely to be illuminating, but must be left for another occasion.

\section{Concluding Remarks}

At least for the purposes of teaching accounting to non-accountants or non-economists, I submit in this short contribution, accounting may be perceived and presented as applied ethics. Systematically gathered support for this hypothesis will, of course, have to be collected to substantiate this point. Doing so will improve the way in which students approach the topic, as people are likely to perceive of their social environment firstly in moral terms. In addition, there are important and substantial ways in which accounting theory is reminiscent of ethics. Economics generally is most akin to the utilitarian strand in economics, emerging from Bentham and Jevons. Accounting, on the other hand, draws on deontological ethics and has strong communitarian overtones. Being explicit about these aspects of accounting may not only improve students' understanding of accounting, but may also open up a discussion for both scholars and practitioners in the field. ${ }^{15}$

\footnotetext{
${ }^{13}$ See Zmyewski \& Hagerman (1981) for an argument in favor of a positivist approach to setting accountancy standards. In view of the discussion here, one might call such an approach a deontological approach.

${ }^{14}$ As of 1 january 2005, IASC accounting rules are adopted in the EU, suggesting the distinction is not between Continental Europe and an Anglo-Saxons, but between the American GAAP, and the European and British IASC.

${ }^{15}$ As one referee has rightfully pointed out, part of the population of practicing accountants might have benefited if in their training the parallels between ethics and accounting had been explicated more.
} 
References

Aristotle (1980) The Nicomachean Ethics. Oxford: Oxford UP.

J. Arthur \& W.H. Shaw (eds., 1991) Justice and Economic Distribution. Englewood Cliffs, NJ: Prentice Hall.

W.J Baumol \& R.E. Quandt (1964) “Rules of Thump and Optimally Imperfect Decisions” American Economic Review 71: 23-46.

T.S. Beauchamp (1982) Philosophical Ethics. New York: McGraw-Hill.

J. Bentham (1970) An Introduction in the Principles of Morals and Legislation. Ed. by J.H. Burns and H.L.A. Hart. London: Athlone.

A. Bhimani (1994) “Accounting and the Emergence of 'Economic Man'” Accounting,Organizations and Society 19(8): 637-674.

H. de Boer (1957) De commissarisfunctie in Nederlandse, ter beurze genoteerde, industriële naamloze vennootschappen, bezien van organisatorisch gezichtspunt. Amsterdam : De Bussy

R.S. Bowman (1997) “Policy Implications of W.S. Jevons’s Economic Theory” Journal of the History of Economic Thought 19: 196-221.

R.B. Brandt (1967) "Some merits of one form of rule-utilitarianism” University of Colorado Studies, pp. 39-65.

J. Burns \& R. Scapens (2000) "Conceptualising Management Accounting Change: An Institutional Framework", Management Accounting Research, 11(1).

D. Carr (1991) Educating the Virtues - An essay on the philosophical psychology of moral development and education. London \& New York: Routledge.

M. Conley \& D. Livermore (1996) “Human Rights, Development and Democracy: The Linkage between Theory and Practice,” Canadian Journal of Development Studies 0(0): 19-36 (special issue).

P. Crittenden (1990) Learning to be Moral: Philosophical Thoughts about Moral Development. London \& New Jersey: Humanities Press International.

J.R. Davis \& R.E. Welton (1991) “Professional Ethics: Business Students’ Perceptions” Journal of Business Ethics 10(6): 451-463.

R.A. Denham, ed. (1991) Ethical Responsibility in Business and the Accounting Profession. University of Alberta.

A.T. Denzau \& D.C. North (1994) “Shared Mental Models: Ideologies and Institutions” Kyklos 47(1): 3-31.

W. Dolfsma (2004) Institutional Economics and the Formation of Preferences. Cheltenham: Edward Elgar.

W. Dolfsma \& B. Mosselmans (1999) Bringing Institutions into Economic Theory: A Return to Jevons. Paper presented at the ESHE conference, February 1999, Valencia, Spain.

W. Dolfsma \& C. Dannreuther (2003) “Subjects and Boundaries: Contesting social capital-based policies” Journal of Economic Issues 37(2).

T. Donaldson \& T.W. Dunfee (1995) “Integrative Social Contract Theory,” Economics and Philosophy 11: 85112.

J.R. Francis (1990) “After Virtue? Accounting as a Moral and Discursive Practice” Accounting, Auditing and Accountability Journal 3(3): 5-17.

R.H. Frank, T. Gilovich and D.T. Regan (1993) “Does Studying Economics Inhibit Cooperation?” Journal of Economic Perspectives 7(2): 159-171.

Friedman, M. (1953) The Methodology of Positive Economics, in: Essays in Positive Economics, Chicago: 
University of Chicago Press, pp.3-43.

W.T. Geary \& R.R. Sims (1994) “Can Ethics be Learned?” Accounting Education 3(1): 3-18

R. Gray, J. Bebbington \& K. McPhail (1994) “Teaching ethics in Accounting and the Ethics of Accounting Teaching” Accounting Education 3(1): 51-74.

D.M. Hausman \& M.S. McPherson (1993) “Taking Ethics Seriously: Economics and Contemporary Moral Philosophy,” Journal of Economic Literature 31(June): 671-731.

Hodgson, G.M. (2001) How Economics Forgot History: the problem of historical specificity in social science. London: Routledge.

----, (1993) “Institutional Economics: surveying the 'old' and the 'new'” Metroeconomica 44(1): 1-28.

W.S. Jevons (1970) The Theory of Political Economy. Ed. by R. Black. Harmondsworth: Pelican.

W.S. Jevons (1981) Jevons Papers and Correspondence. Ed. by R.D. Black et al. London \& Basingstoke: MacMillan.

A. Klamer and D. Colander (1990) The Making of an Economist. Boulder: Westview Press

L. Kohlberg (1981) The Philosophy of Moral Development. Vol. I-III, San Francisco, Ca.: Harper \& Row. K.J. Lancaster (ed., 1998) Consumer Theory. Cheltenham: Edward Elgar.

A.T.A. Lovell (1995) “Moral Reasoning and Moral Atmosphere in the Domain of Accounting” Accounting, Auditing and Accountability Journal 6(2): 147-162.

P. Mirowski (1989) More Heat than Light: Economics as Social Physics, Physics as Nature's Economics. Cambridge \& New York: Cambridge U.P.

M. de Montaigne, M. de (1991) The Complete Essays (trans. by Michael Screech), London: Penguin.

G.E. Moore (1903) Principia Ethica. Cambridge, England: Cambridge UP.

D.C. North (1990) Institutions, Institutional Change and Economic Performance. New York: Cambridge UP.

M. Peacock (2004) Everyday Conceptions of Justice and their Role in Economics. Paper presented at the World Congress for Social Economics, July 2004, Albertville, France.

L.A. Ponemon (1992) “Ethical Reasoning and Selection-Socialization in Accounting” Accounting,Organizations and Society 17(3/4): 239-258.

A. Puxty, P. Sikka \& H. Willmott (1994) “(Re)forming the circle: education, ethics and accountancy practices” Accounting Education 3(1): 77-92.

J. Rawls (1971) A Theory of Justice. Cambridge, Mass.: Belknap Press of Harvard UP.

J.R. Rest (1986) Moral Development: Advances in Research and Theory. New York: Praeger.

P.V. Rosenau (2004) New Evidence to Revise the Old Economics; Making Society Safe for contingent Cooperators. Paper presented at the Communitarian Summit, July 2004, Washington DC.

J.J.C. Smart (1973) “An outline of a system of utilitarian ethics” in: J.J.C. Smart \& B.Williams (eds.)

Utilitarianism: For and Against. Cambridge, England: Cambridge UP.

A. Smith (1976 [1759]) The Theory of Moral Sentiments. Indianapolis: Liberty, ed. D. Raphael \& A. Macfie.

----, (1976 [1776]) An Inquiry into the Nature and Causes of the Wealth of Nations. Indianapolis: Liberty, ed. by

R. Campbell \& A. Skinner (2 volumes).

I. van Staveren (2001) The Values of Economics: an Aristotelean Perspective. London: Routledge.

G.J. Stigler (1968 [1950]) “The Development of Utility Theory. In: A.N. Page (ed.) Utility Theory: A book of reading. New York: John Wiley \& Sons, pp. 59-119. [Reprinted from: Journal of Political Economy 58: 
307-27 and 373-96, August and October.]

P.G.A. de Wal (1927) De Leer van het Boekhouden in de Nederlanden tijdens de Zestiende Eeuw [Bookkeeping in the Netherlands during the $16^{\text {th }}$ Century]. Roermond: J.J. Romen \& Zonen.

M. Walzer (1983) Spheres of Justice. Basic Books.

M.V. White (1994) “Following Strange Gods: Women in Jevon’s Political Economy” in: P.Groenewegen (ed.) Feminism and Political Economy in Victorian England. Aldershot: Edward Elgar, pp. 46-78.

M.E. Zmyewski \& R.L. Hagerman (1981) "A Test of Accounting Bias and Market Structure: Some Additional Evidence" Review of Business and Economic Research. Fall, pp.84-88. 


\section{Publications in the ERIM Report Series Research* in Management}

\section{ERIM Research Program: "Organizing for Performance"}

2005

Continuous versus Step-Level Public Good Games

Susanne Abele and Garold Stasser

ERS-2005-015-ORG

$\underline{\text { http://hdl.handle.net/1765/1937 }}$

Collective Consuming: Consumers as Subcontractors on Electronic Markets

Wilfred Dolfsma

ERS-2005-020-ORG

$\underline{\text { http://hdl.handle.net/1765/1932 }}$

Appropriability in Services

Wilfred Dolfsma

ERS-2005-021-ORG

http://hdl.handle.net/1765/1926

Is China a Leviathan?

Ze Zhu

ERS-2005-031-ORG

http://hdl.handle.net/1765/6551

Information Sharing and Cognitive Centrality

Susanne Abele, Garold Stasser and Sandra I. Vaughan-Parsons

ERS-2005-037-ORG

$\underline{\text { http://hdl.handle.net/1765/6664 }}$

Virtual Enterprises, Mobile Markets and Volatile Customers

Ferdinand Jaspers, Willem Hulsink and Jules Theeuwes

ERS-2005-039-ORG

http://hdl.handle.net/1765/6728

No Black Box and No Black Hole: from Social Capital to Gift Exchange

Rene van der Eijk, Wilfred Dolfsma and Albert Jolink

ERS-2005-040-ORG

http://hdl.handle.net/1765/6665

Boards in Agricultural Cooperatives: Competence, Authority, and Incentives

G.W.J. Hendrikse

ERS-2005-042-ORG

$\underline{\text { http://hdl.handle.net/1765/6883 }}$

The Protestant Work Ethic and Group Performance

Susanne Abele and Michael Diehl

ERS-2005-053-ORG

http://hdl.handle.net/1765/6990

Organization and Strategy of Farmer Specialized Cooperatives in China Yamei Hu, Zuhui Huang, George Hendrikse and Xuchu Xu

ERS-2005-059-ORG

$\underline{\text { http://hdl.handle.net/1765/6995 }}$ 
The Influence of Employee Communication on Strategic Business Alignment

Cees B. M. van Riel, Guido Berens and Majorie Dijkstra

ERS-2005-060-ORG

http://hdl.handle.net/1765/6996

The Tsunami's CSR Effect: MNEs and Philanthropic Responses to the Disaster

Gail Whiteman, Alan Muller, Judith van der Voort, Jeroen van Wijk, Lucas Meijs and Cynthia Piqué

ERS-2005-062-ORG

http://hdl.handle.net/1765/6994

Bridging Structure and Agency: Processes of Institutional Change

Wilfred Dolfsma and Rudi Verburg

ERS-2005-064-ORG

http://hdl.handle.net/1765/7014

Accounting as Applied Ethics: Teaching a Discipline

Wilfred Dolfsma

ERS-2005-065-ORG

* A complete overview of the ERIM Report Series Research in Management: https://ep.eur.nl/handle/1765/1

ERIM Research Programs:

LIS Business Processes, Logistics and Information Systems

ORG Organizing for Performance

MKT Marketing

F\&A Finance and Accounting

STR Strategy and Entrepreneurship 